\title{
Teaching of Physical Education: Focus on the Teaching Preferences of Teachers of Brazzaville
}

\author{
David Sylvain Mabassa ${ }^{1 *}$, Gorgon Lembe ${ }^{1}$, Armel Koulombo ${ }^{1}$, Jean Itoua Okemba1,2 \\ ${ }^{1}$ Laboratory of Didactics of Physical Education, Higher Institute of Physical Education, Marien Ngouabi University, Brazzaville, \\ Congo \\ ${ }^{2}$ Laboratory for Studies and Research in Adapted Physical Activities, Higher Institute of Physical Education and Sports, Marien \\ Ngouabi University, Brazzaville, Congo \\ Email:^dmabassa@googlemail.com
}

How to cite this paper: Mabassa, D. S., Lembe, G., Koulombo, A., \& Okemba, J. I. (2020). Teaching of Physical Education: Focus on the Teaching Preferences of Teachers of Brazzaville. Open Journal of Social Sciences, 8, 99-111. https://doi.org/10.4236/jss.2020.87009

Received: June 12, 2020

Accepted: July 11, 2020

Published: July 14, 2020

Copyright $\odot 2020$ by author(s) and Scientific Research Publishing Inc. This work is licensed under the Creative Commons Attribution International License (CC BY 4.0).

http://creativecommons.org/licenses/by/4.0/

(c) (i) Open Access

\begin{abstract}
The purpose of this study is to identify the pedagogical preferences of the teacher that appear in the physical education lesson during the assessments and the pedagogical relationship with the students. The study was carried out in the colleges of Brazzaville, during the 2018-2019 school years. Twelve (12) EPS teachers from 24 educational classes participated in the study after drawing lots. That is, 296 students aged 12 to 16 told stories about feelings of injustice, prejudice experienced or perceived during the physical education lesson with their teacher. Brunelle's critical incident sampling technique was used to capture the preferences of the teacher who most appealed to students. Then they completed, individually and as many times as they wanted, a form with the following instructions: "Tell us about a situation that happened in physical education that you found unfair to you or other students. Describe more precisely (when, who, what) what happened in this situation." The results obtained showed that out of 06 families of preferences, 154 stories told by students $(41 \%)$ were dominated by the management of the physical education lesson. Then, out of 18 categories of preferences, 7 were linked to the management of the discipline; the results revealed that 53 stories told by pupils entailed too severe sanctions and 41 stories told by pupils led to pedagogical punishments and evocations without right. Thus, students must perceive the need in their relationship with their physical education teacher so that they can, if necessary, express their disagreement with the treatment they are receiving or witnessing.
\end{abstract}

\section{Keywords}

Pedagogical Preferences, Teacher, Pupil, Physical Education Lessons 


\section{Introduction}

The teaching-learning process is determined by both the teacher and the student in the educational context (Dyson, 1995). However, this learning climate is often marked by the dominance of teachers' feelings of preference. From this flows the cry of indignation that has been living in the students since the start of school. According to Dubet et al., (2011), the feeling of preferences in France is built from elementary school (from 6 years old) and evolves with age. High school students are more sensitive to merit problems, if only because of the play of orientations and streams, the weight of the school report, the role of grades, etc. However, many students discover that the work provided in physical education does not guarantee the mark. At the same time, high school students are keenly aware of the contradictory nature of the principles of equality and the principles of merit. At middle school, Debardieux (1990) reveal that feelings of preferences appear in different areas, in terms of evaluation in physical education, orientation decisions, educational relationship, punishments, the impossibility of complaining or even the assignment in a class which mainly includes weak students (bad class).

In the field of educational sciences, several studies carried out on the feelings of preferences of students in physical education show that they have an impact on learning (Meuret, 1999). In physical education, this aspect has also been noted, as the Canadian study by Martel et al., (1999). Indeed, during the physical education lesson, the notional contents are taught and evaluated in the masculine, the planning of the situations has a "masculine" connotation, the practices are "foreign" for the girls, and the scales little sensitive to the differences genetics (Cleuziou, 2000). Teacher-student interactions are characterized by unequal treatment; they are often in favor of boys (Couchot-Schiex et al., 2009). For example, the male orientation in gymnastics favors the success of boys than that of girls (Combaz et al., 2009; Cleuziou, 2000; Vigneron, 2006). These inequalities between girls and boys accentuate the feeling of preferences among girls. In addition, feelings of preferences are most often observed in terms of assessment and punishment (Debarbieux, 1990). To better elucidate the feeling of preferences in physical education, research pays particular attention to students' perceptions, since these latter implicitly or explicitly influence learning. It is in this sense that Weisser (2010) note that the opinions of students on the situations experienced in physical education make it possible to understand the meaning of the behaviors they adopt. Often these revelations from students focus on the situations of preferences experienced in physical education. Other studies have shown that preference situations, which are frequent in the field, have harmful effects on the classroom climate and student learning.

In addition, during the evaluations, the activities selected by the teacher favor boys more than girls (Scraton, 1992). This is how pupils weak in physical education receive less encouragement (Martinek \& Karper, 1986); they also benefit from fewer opportunities to participate in the construction of learning and answers to 
questions from the teacher. They have little interaction with their teacher and receive less information about expected motor behaviors (Brown, 1979; Martinek, 1989; Martinek \& Karper, 1986).

In Congo, the general situation facing this problem is almost identical to that of Europe and America. However, preferences are found in the management of sports activities selected during the physical education lesson through classroom management and assessments. For example, a report by the General Inspectorate of Physical Education and Sports (MSEP, 2015) noted that in the second cycle girls express more feelings of injustice compared to boys with regard to teaching practices. However, situations of repeated preferences "attack the educational relationship at its heart" (Desvignes \& Meuret, 2009), or even accompany anger, violence, delinquency (Bodin et al., 2006). The declarations of the pupils (girls or boys) regarding the preferences experienced in physical education then constitute a source of information of primary importance for the teachers in order to adapt their lessons to the expectations of these pupils without distinction of sex and they are of a of great importance for the process of regulation of education. In view of the above, we can ask the following question: where does the injustice reside among the students during the physical education lesson? In other words, do the feelings of injustice perceived by students have their origins in the strategies used by teachers in classroom management and assessments? To explain this situation, the mediating variable most often mentioned in these preferences refers to beliefs about feelings of injustice and personal efficiency according to the theory put forward by Hadji (1996). Faced with this questioning, we hypothetized that: the evaluations and the educational relationship reflect the feelings of injustice manifested by the teacher and experienced by the students through the behaviors they adopt in physical education. Thus, the objectives of this study are: 1) to identify and categorize the feelings of injustice perceived by students during physical education lessons; 2) to list the preferences reported by the students and related to: discipline management, learning activities, lesson time management, teacher preferences, peer behaviors and student judgments' teacher.

The interest of this study is to raise awareness in the Congolese educational community on the injustices caused by the physical education teacher during the assessments and the pedagogical relationship with the students. The teacher must guide his pedagogical action according to the students. Because, if their expectations are taken into account, the students will be more satisfied with this teaching, and ipso facto the teachers' work will be facilitated.

\section{Materials and Methods}

\subsection{Period and Tailling of Study}

The study was carried out in a municipality in the capital city of Brazzaville, Congo, from November 10, 2018 to April 20, 2019. Among the 9 municipalities in this city, a simple random selection made it possible to select it. The popula- 
tion of the commune was estimated at 275,327 inhabitants, with a school population of 72,144 pupils. The number of establishments recorded in this municipality was 35 primary schools, 29 middle schools and 5 high schools. This study focused on middle school students, since physical education teaching first appeared as a school teaching discipline in the Congo among 11 other disciplines taught (mathematics, physics and chemistry, earth and earth sciences, history and geography, French, English, civics, music, drawing); the coefficient allocated to this discipline is 2 (MEN, 2007). A further study will take into account the pupils of the lycées. However, two criteria for inclusion of colleges were: the existence of appropriate sports facilities; oral and written consent from school officials. Three colleges were chosen to participate in the study.

\subsection{Sample}

Twelve physical education teachers ( 5 women, 7 men), at the rate of four teachers per establishment, who attended the colleges participated in the study after drawing lots. These teachers, whose professional experience varied from 5 to 10 years, selected a class from among the four levels of study in the college. Thus, 12 classes were selected to participate in the experiment. However, only three classes were selected by three successive single draws, for a total of 296 pupils (154 girls, 142 boys) aged 12 - 16 years.

\subsection{Data Collection Tools}

Successful students were asked to discuss feelings of preferences experienced or perceived during the physical education lesson with their teacher. The critical incident sampling technique of Brunelle et al. (1988) was used to collect the preferences that most appealed to students. In each class, students were interviewed in the absence of their physical education teacher so that they could express themselves freely and confidentially. In addition, they completed individually and as many times as they wanted, a form with the following instructions: "Tell us about a situation that happened in physical education that you found unfair for you or other students. Describe more precisely (when, who, what) what happened in this situation".

\subsection{Analysis of the Situations Reported by the Students}

The situations of injustice reported $(\mathrm{N}=372)$ by the students were the subject of an open content analysis (L'Écuyer, 1988). This made it possible to group together those who presented affinities under appropriate names, thus allowing the emergence of a typology which identifies the categories of preferences experienced by the students. The validity of this typology was established in three stages. During the first stage, two researchers classified all of the situations collected on the basis of an inter-judge agreement. In the second step, a third researcher, not involved in the development of the typology, was asked to classify again $20 \%$ of the situations already grouped in each of the preference categories, 
without knowing the initial classification. This third researcher accurately classified $85 \%$ (loyalty coefficient) of the situations selected. The third step allowed the three researchers to refine the typology by correcting, if necessary, the names of the preference categories and by obtaining a consensus on the classification of the statements for which there were disagreements during the fidelity test. Subsequently, the preference categories were grouped into six families based on the object of injustice reported by the students within each of the categories. For example, the preference categories "Give too harsh sanctions", "Punish or reason with students for no reason", "Lack respect for students", "Be inconsistent in applying rules of conduct" and "Establish unsuitable or not appropriate rules of conduct" have been grouped into the family of preferences called "Discipline management".

\subsection{Data Analysis}

The preferences reported by the students are presented in terms of enrollment and percentages, the number of teachers concerned is also indicated. The Epi Info software version 6.1.1 was used to process the data obtained.

\section{Results}

The results obtained in this study are presented in such a way as to feel clearly the point of view of the students in the face of the unfair situations they have reported.

\subsection{Preferred Families}

The families of preferences are distributed according to the stories told by each student.

\subsection{Preferences Categories}

The categories that make up the typology of preferences reported by the students are presented in Tables 2-7 for each of the families of preferences. These tables specify the number of stories told by the students as well as the number of teachers concerned for each of the preference categories.

\section{Discussion}

The purpose of the study was to identify the teacher's pedagogical preferences that appear in the physical education lesson during assessments and the pedagogical relationship with students. The data obtained show that the evocations of the students touch the unfair situations they live in physical education class, these seem to reveal learning conditions unfavorable to their development.

\subsection{Preferred Families}

The 6 families of preferences, resulting from the regrouping of the 18 categories of the typology of preferences, are presented in Table 1. This table specifies the 
number of stories told by the pupils as well as the number of physical education teachers concerned for each of the preference families. The results of this Table 1 reveal that the students mainly denounce preferences associated with the management of the physical education lesson. More specifically, $41 \%$ of the unfair situations reported by students question the way their physical education teacher manages this discipline. It should also be noted that all of the teachers who participated in the study are subject to this criticism from their students.

In addition, many students perceive deficiencies in the learning activities offered by their teacher since $18 \%$ of the stories relate to the organization of these activities and their nature. These deficiencies are so important for the pupils of the 12 classes visited that they make learning activities bear preferences. This can probably be explained by the monotony of the learning situations, the inadequate management of the motor engagement time, the distribution of the practice time between the students in the workshops and the unnecessary waste of time in the explanations. Accounts relating to poor management of working time account for $16 \%$ of all unfair situations reported by students and concern 07 of the 12 teachers in the study. Finally, 11\% of the preferences reported are attributable to privileged treatments which some students benefit from, $9 \%$ are caused by inappropriate student behavior and only $5 \%$ relate to errors in the teacher's judgment, mainly in evaluation situations.

On this subject, Brunelle \& Brunelle (2012) and Martel et al., (1996) reveal that the strategies imprint authoritarianism and constitute without refutation, fl agrant preferences for the pupils. The recurrent use of authoritarian interventions by the physical education teacher creates in the students a state of conformism which leads them to submit and experience silent internal violence and without autonomy and generates an escalation of disruptive behavior in other students.

\subsection{Preferences Categories}

\subsubsection{Preferences Related to Discipline Management}

Students out of 9 teachers reported 53 situations (Table 2) where they felt their

Table 1. Presents the distribution of stories told by students according to families of preferences.

\begin{tabular}{cccc}
\hline Preferred families & $\begin{array}{c}\text { Number of teachers } \\
\text { involved }\end{array}$ & $\begin{array}{c}\text { Number of stories } \\
\text { narrated }\end{array}$ & $\begin{array}{c}\text { Percentage } \\
(\%)\end{array}$ \\
\hline Discipline management & 12 & 154 & 41 \\
Learning activities & 12 & 67 & 18 \\
Management of time & 7 & 58 & 16 \\
Teacher preferences & 9 & 40 & 11 \\
Peer behaviors & 9 & 34 & 9 \\
Teacher judgment & 9 & 19 & 5 \\
\hline
\end{tabular}


teacher was too harsh on them. Then the pupils consider that the physical education teacher abuses his authority when he reacts to one or other of their deviant behaviors.

However, many students question the legitimacy of disciplinary sanctions imposed on them. In this regard, 41 stories told (Table 2) by pupils about physical education teachers report punishments or reprimands deemed undeserved and suffer group punishments. In addition, according to the stories of their students, 7 teachers sometimes seem to disrespect them. This lack of respect takes various educational forms: embarrassing, even humiliating situations, derogatory remarks. Finally, 18 stories (Table 2) reflect student criticism of 7 physical education teachers who appear to be inconsistent in applying the sanctions associated with rules of conduct which they deem inappropriate.

In light of the above, Dostie (1996) indicates that it is important that only the student concerned be punished for their misconduct. Also, the teacher should not have the impression of being attacked personally by the teacher, he should rather feel that it is the behavior he has adopted that is harmful and must be corrected. He's not the bad guy. In addition, a new fault must be treated objectively as an isolated event where only the immediate disruptive behavior is considered by the teacher. In this way, his intervention carries less emotional charge than if his reaction is tinged with accumulated frustration. For Dostie (1996), the student can thus feel that his whole personality is not in question, that he has the chance to recover and that he will not have to constantly bear the burden of his past. Obviously, adhering to this type of intervention requires the teacher to admit the limits of his usual repertoire of reactions. The latter must also prepare to use this more educational approach on a regular and prolonged basis if he wants to perceive the real benefits for his students and himself.

Table 2. Preferences related to the management of the physical education lesson.

\begin{tabular}{lcc}
\hline \multicolumn{1}{c}{ Preferences categories } & $\begin{array}{c}\text { Number of teachers } \\
\text { concerned }\end{array}$ & $\begin{array}{c}\text { Number of stories } \\
\text { narrated }\end{array}$ \\
\hline $\begin{array}{l}\text { Give too harsh sanctions: laps, push-ups, abs } \\
\text { Punish students for no reason: }\end{array}$ & 9 & 53 \\
$\begin{array}{l}\text { early learning material arrangements and at } \\
\text { the end of the physical education lesson }\end{array}$ & 8 & 41 \\
$\begin{array}{l}\text { Disrespecting students: } \\
\text { By reasoning when they make errors or } \\
\text { don't understand }\end{array}$ & 4 & 18 \\
By making remarks to them derogatory & 5 & 6 \\
B By placing them in awkward situations & 2 & 18 \\
Being inconsistent in applying the rules of conduct & 7 & 7 \\
Introducing inappropriate rules of conduct & 1 & \\
\hline
\end{tabular}




\subsubsection{Preferences Related to Learning Activities}

According to students from the 3 classes visited (Table 3), the team-building process recommended by their physical education teacher generates overwhelming preferences. In fact, 36 stories relate to situations where the training of teams causes harm. Some students feel that their physical education teacher creates teams of uneven composition when they themselves designate the students who make up each team. When he makes teams, they are poorly structured. The best are in one team and the worst in the other. Others denounce the ineffectiveness of team formation from class leaders who take turns selecting their teammates. Finally, students are sensitive to the discomfort that the team-building process can cause. When we make teams, some students are not chosen. The physical education teacher is obliged to put them himself in a team. A few stories also suggest that some of the students find their teachers uncompromising with peers who experience discomfort in physical education. The following examples illustrate this sensitivity of pupils with regard to the treatment accorded to their peers whom they consider to be in difficulty: During physical education, when there are sick pupils living with a handicap (asthma, diabetes, obesity, sickle cell anemia) the teacher forces them to do the learning activities. Finally, the students expressed their fear at the conditions for carrying out certain activities proposed by their teacher. One of them tells the following story: some routes and obstacles are dangerous or impossible. The high jump is performed on the ground, there is no landing foam. The teacher never thought that a student could hang their feet on the bar and fall when their feet, arms or wrists were broken. Students find this to be far too dangerous and should replace landing foam instead.

We can safely say that this behavior displayed by the physical education teacher is the direct consequence of the lack of material, the poor structure of the class and the absence of a teaching program physical education adapted to students living with disabilities. On this subject, Florence (1986) presents five criteria which make it possible to plan learning tasks, which are from their presentation, from the first attempts, positively perceived and received by the pupils. Concretely, a teacher must propose a learning task which:

Table 3. Preferences linked to learning activities.

\begin{tabular}{lcc}
\hline \multicolumn{1}{c}{ Preferences categories } & $\begin{array}{c}\text { Number of stories } \\
\text { told }\end{array}$ & $\begin{array}{c}\text { Number of teachers } \\
\text { involved }\end{array}$ \\
\hline Use inappropriate training activities: & 25 & 11 \\
- teams poorly structured in number or in kind & 11 & 6 \\
- which causes trauma in some students & 25 & 7 \\
Offer monotonous activities & 4 & 3 \\
Require student participation & 2 & 1 \\
Propose dangerous activities & & \\
\hline
\end{tabular}


- asks the student to move through several movements, where the whole body is involved (dynamism of the task);

- arouses his astonishment and curiosity (originality of the task);

- has a level of difficulty adapted to his skill level (task load); offers him variations in order to adapt the task to his skill level, to his ideas of evolution (opening of the task);

- ensures the link with the objective of the lesson (sense of the task).

Thus, Florence (1986) also specifies that any task of learning a lesson does not necessarily have to meet all the criteria simultaneously, that is to say that it is up to the teacher "to saturate his exercises by such and/or such criteria in order to make each of them as stimulating as possible".

\subsubsection{Time Management Preferences}

The pupils of 7 physical education teachers believe that the latter do not distribute the practice time evenly among the pupils (Table 4). In fact, no fewer than 37 stories maintain that teams play more often than others during physical education classes, then boys have more learning opportunities than girls. Students' comments in this regard are generally unequivocal. Students of 4 physical education teachers also consider that their teacher wastes their time. Among them, some criticize their teacher for speaking too long or too frequently, which makes them waste time in practice. As for the others, they denounce the lack of rigor of their teacher in the face of disruptive behavior which breaks the rhythm of the lesson: the girls disturb during physical education lessons. At the start of the course, they comb their hair as if they were in a hair salon. They arrive late and that wastes our time. Because of them, the lessons are shorter and we play less. The teacher doesn't even punish them.

In view of the above, we can safely say that it is important for a teacher to strike a balance between the need to pass on information and the need to provide students with optimal practice time. All the more, as Brunelle \& Brunelle (2012), that excessively long periods of time devoted to explanations, the organization of the group and the equipment, as well as long waiting times during the course of an activity, contribute to creating a drop in interest in students and sometimes even a climate of hostility.

Table 4. Time management preferences.

\begin{tabular}{lcc}
\hline \multicolumn{1}{c}{ Preferences categories } & $\begin{array}{c}\text { Number of stories } \\
\text { told }\end{array}$ & $\begin{array}{c}\text { Number of teachers } \\
\text { involved }\end{array}$ \\
\hline Offer less practice time to certain students & 37 & 7 \\
To waste time: & 21 & 3 \\
- speaking too long or too frequently & 13 & 2 \\
\hline
\end{tabular}




\subsubsection{Preferences Related to Teacher Preferences}

Six of the twelve teachers who participated in this study are accused of always choosing the same students to perform motor tasks such as demonstrating the gymnastic elements, team captains, officials, judges, umpires or going out, install and store the teaching materials (Table 5). For the students, 23 stories represent undeniable proof that their teacher prefers some of their peers. In addition, students from six of the physical education teachers report 17 stories where they believe that their teacher, under certain circumstances, does not provide students with the educational support they need. For example, students say that their teacher sometimes lacks compassion, improvement towards them. Other students denounce the fact that their teacher congratulates the learning and helps some students in the workshops more than others. Finally, some students explain that their teacher completely ignores them when they are ridiculed by their peers. In this regard, we share the comments of Brunelle \& Brunelle (2012) who invite teachers to eliminate the caustic criticism which is known to have a harmful influence on learning and personal development. More specifically, countering a situation that is so detrimental to the students' development requires that the teacher adopt more positive behaviors, which are generally part of his repertoire of interventions, and which he uses, probably naturally and unconsciously, with of some students.

\subsubsection{Preferences Related to Peer Behaviors}

Students in 6 of the study's physical education teachers share 19 stories where they believe the inappropriate behavior of some of their peers creates hurtful situations for some students (Table 6). The sarcasm and criticism formulated by these pupils constitute real preferences for the pupils who undergo them or who witness them. In addition, students from 5 of the 12 teachers report 15 stories in which they point out that arbitration errors and cheating by their peers are a source of injustice and frustration. We can explain this by the inappropriate behaviors of some students which create hurtful situations for some of their peers. As Brunelle \& Brunelle (2012), the presence of a supportive atmosphere can play

Table 5. Preferences linked to teacher preferences.

\begin{tabular}{ccc}
\hline \multicolumn{1}{c}{ Preferences categories } & Number of stories told & Number of teachers \\
\hline $\begin{array}{l}\text { Always choose the same students to demonstrate, } \\
\text { be a team leader or put away the equipment }\end{array}$ & 23 & 6 \\
Offer less support to certain students & 17 & 6 \\
\hline
\end{tabular}

Table 6. Preferences linked to peer behaviors.

\begin{tabular}{ccc}
\hline Preferences categories & Number of stories told & Number of teachers \\
\hline Ridicule, annoy or criticize their peers & 19 & 6 \\
Make refereeing errors or cheat & 15 & 5
\end{tabular}


an important role in producing constructive reactions towards students. Here, the teacher could try to get students to become reinforcement agents with their peers in a way that creates a caring atmosphere.

\subsubsection{Preferences Related to the Teacher's Judgment}

Students of 5 physical education teachers tell 14 stories where they believe the evaluation process initiated by their teacher is damaging (Table 7). Some consider only their teacher to set standards and rules of play that favor girls over boys. Other students find that their teacher sometimes lacks discernment or congruence when assessing them. Finally, some students from four of the 12 teachers express their frustration caused by their teacher's referee errors. The words reported by the students confirm the necessity and the relevance of asking them about the learning conditions they experience during their physical education lessons. Without a doubt, their revelations have brought to light the actions of physical educators who deserve to be reconsidered in order to provide more equitable learning conditions. Obviously, it is up to the physical educators to qualify the words of their students taking into account the characteristics of their professional environment. However, they must recognize the multiple sources of preferences inherent in teaching physical education, admit that students' discomfort with these preferences often escapes their vigilance and accept the fact that sometimes they do not not suspect or underestimate the perverse effects of some of their teaching strategies. Finally, it is essential for physical educators to use the perceptions of their students as one of the sources of information likely to favor.

However, our results take into account the complexity of the professional mission of the physical education teacher. It must be recognized that any teacher is likely, consciously or unconsciously, to adopt behaviors that are perceived and interpreted unfavorably by his students. A multitude of factors such as student behaviors and their level of success can also influence teachers' behavior and lead them to develop preferences or aversions towards some of them (Martel et al., 1996). Furthermore, it is plausible to believe that students, in certain circumstances, formulate their remarks without being aware of the pedagogical constraints faced by their teacher. On the other hand, teachers must admit that their interventions, although based on praiseworthy teaching strategies, can sometimes have real unwanted effects and above all, unfavorable to the development of their students. In fact, they must ask themselves more about the effects produced by their actions much more than their legitimacy (Martel et al., 1996).

Table 7. Preferences linked to the teacher's judgment.

\begin{tabular}{ccc}
\hline Preferences categories & Number of stories told & Number of teachers \\
\hline Evaluate too severely & 14 & 5 \\
Make refereeing errors & 5 & 4 \\
\hline
\end{tabular}




\section{Conclusion}

The purpose of the study was to identify the pedagogical preferences of the teacher that appeared in the physical education lesson during assessments and the pedagogical relationship with the students. The hypothesis that the assessments and the educational relationship reflect the feelings of injustice manifested by the teacher and experienced by the students through the behaviors they adopt in physical education has been verified. To do this, it is the teacher's responsibility to regulate the quality of the teaching process and to create a climate of trust that will allow students to express their opinion openly without fear of reprisal. Thus, students must perceive the openness necessary in their relationship with their teacher so that they can, if necessary, express their disagreement with the treatment they are subject to or of which they are witnesses. If the teacherstudent relationship, on the other hand, is not very collaborative, students will be rather fearful or embarrassed to express their point of view.

\section{Conflicts of Interest}

The authors declare no conflicts of interest regarding the publication of this paper.

\section{References}

Bodin, D., Robène, L., Héas, S., \& Blaya, C. (2006). Violences à l'école: L'impact de la matière enseignée. Déviance et Société, 30, 21-40. https://doi.org/10.3917/ds.301.0021

Brown, J. P. (1979). Description of Dyadic Student-Teacher Interaction in the Physical Education Activity Class. Thèse de doctorat en science de l'exercice et du sport, Greensboro: University of North Carolina.

Brunelle, J., Drouin, D., Godbout, P., \& Tousignant, M. (1988). La supervision de l'intervention en activité physique. Montréal: Gaëtan Morin.

Brunelle, M., \& Brunelle, A. (2012). Pratiques enseignantes: Des recherches a confortees et a developper. Revue Francaise de Pedagogie, 138, 63-74. https://doi.org/10.3406/rfp.2002.2864

Cleuziou, J.-P. (2000). L'analyse des menus et des notes. In B. David (Ed.), Éducation physique et sportive: La certification au baccalauréat (p. 77-124). Paris: INRP.

Couchot-Schiex, S., Cogérino, G., \& Coltice, M. (2009). Professeurs stagiaires en EPS face à l'enseignement en mixité. Carrefours de l'Education, 27, 169-182. https://doi.org/10.3917/cdle.027.0169

Debarbieux, E. (1990). La violence dans la classe. Paris: ESF.

Desvignes, S., \& Meuret, D. (2009). Les sentiments de justice des élèves en France et pourquoi. In M. Duru-Bellat, \& D. Meuret (Eds.), Les sentiments de justice à et sur l'école (pp. 187-199). Paris: De Boeck Supérieur, Pédagogies en développement.

Dostie, S. (1996). Analyse d'incidents disciplinaires vécus par des éducateurs physiques au primaire. Mémoire de maîtrise en sciences de l'activité physique. Département des sciences de l'activité physique, Université du Québec à Trois-Rivières.

Dubet, F., Duru-Bellat, M., \& Vérétout, A. (2011). Emprise des diplômes, jugements de justice et cohésion sociale. Sociologie et sociétés, 43, 225-259.

https://doi.org/10.7202/1003538ar 
Dyson, B. P. (1995). Students' Voices in Alternative Elementary Physical Education Programs. Journal of Teaching in Physical Education, 14, 394-407. https://doi.org/10.1123/jtpe.14.4.394

Florence, J. (1986). Motivations et buts d'action en éducation physique scolaire, CIACO. Louvain-la-Neuve: Éditions scientifiques et universitaires.

Hadji, C. (1996). L'évaluation des apprentissages en éducation physique. Paris: Edtions Vigot

L'Écuyer, R. (1988). L'analyse de contenu: Notion et étapes. In J. P. Deslauriers (Ed.), Les méthodes de la recherche qualitative (pp. 49-65). Québec: Presses de l'Université du Québec.

Martel, D., Gagnon, J., Brunelle, J. P., \& Spallanzani, C. (1996). Comportements d'élèves qui influencent le développement d'attentes chez les enseignants et enseignantes en éducation physique. Revue Avante, 2, 37-49.

Martel, D., Gagnon, J., Grenier, J., \& Pelletier-Murphy, J. (1999). Révélations d'élèves du primaire sur la conduite de l'éducateur physique à leur égard. In J. F. Grehaigne, D. Marchal, \& N. Mahut (Eds.), Actes du Congrès de l'AIESEP Qu'apprennent les élèves en faisant des activités physiques. Besançon: IUFM-Franche Comté.

Martinek, T. J. (1989). The Psycho-Social Dynamics of the Pygmalion Phenomenon in Physical Education and Sport. In T. J. Templin, \& P. G. Schempp (Eds.), Learning to Teach: Socialisation into Physical Education (pp. 199-217). Indianapolis, IN: Benchmark Press Inc.

Martinek, T. J., \& Karper, W. B. (1986). Motor Ability and Instructional Contexts: Effects on Teacher Expectations and Dyadic Interactions in Elementary Physical Education Classes. Journal of Classroom Interaction, 21, 16-25.

MEN (2007). Rapport du colloque bilan sur l'enseignement secondaire, années 20002005. Brazzaville: Ministère de l'Education Nationale.

Meuret, D. (1999). Rawls, l'éducation et l'égalité des chances. In D. Meuret (Ed.), La justice du système éducatif(12 p.). De Boeck.

MSEP (2015). Barèmes et coefficients des disciplines scolaires dans l'enseignement secondaire. Brazzaville: Ministère des Sports, de l'Education Physique et Sportive.

Scraton, S. (1992). Shaping Up to Womanhood: Gender and Girls' Physical Education. Buckingham: Open University Press.

Vigneron, C. (2006). Les inégalités de réussite en EPS entre filles et garçons: Déterminisme biologique ou fabrication scolaire? Revue Française de Pédagogie, 154, 111-124. https://doi.org/10.4000/rfp.146

Weisser, M. (2010). Dispositif didactique? Dispositif pédagogique? Situations d'apprentissage. Recherches en Education, 4, 291-303. https://doi.org/10.4000/questionsvives.271 